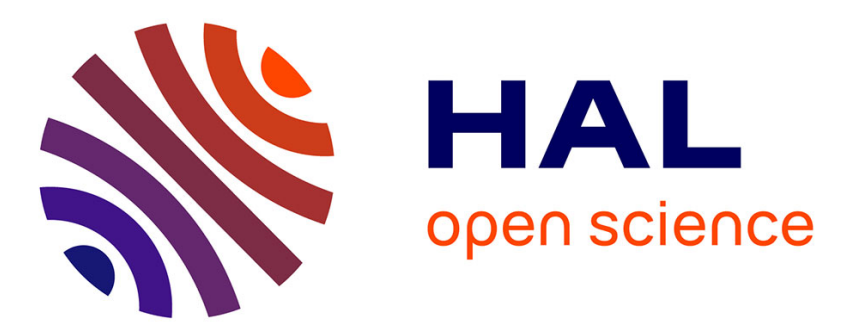

\title{
Reaction of European Bank Stock Prices to Events of the Asian and Russian Financial Crises
}

Céline Meslier-Crouzille, Laetitia Lepetit, Amine Tarazi

\section{To cite this version:}

Céline Meslier-Crouzille, Laetitia Lepetit, Amine Tarazi. Reaction of European Bank Stock Prices to Events of the Asian and Russian Financial Crises. 2006. hal-00918567

\section{HAL Id: hal-00918567 \\ https://hal-unilim.archives-ouvertes.fr/hal-00918567}

Preprint submitted on 13 Dec 2013

HAL is a multi-disciplinary open access archive for the deposit and dissemination of scientific research documents, whether they are published or not. The documents may come from teaching and research institutions in France or abroad, or from public or private research centers.
L'archive ouverte pluridisciplinaire HAL, est destinée au dépôt et à la diffusion de documents scientifiques de niveau recherche, publiés ou non, émanant des établissements d'enseignement et de recherche français ou étrangers, des laboratoires publics ou privés. 


\title{
Reaction of European Bank stock prices to events of the Asian and Russian Financial crises
}

\author{
Céline Crouzille, Laetitia Lepetit, Amine Tarazi` \\ Université de Limoges, LAPE, 4 place du Présidial, 87031 Limoges, France
}

\begin{abstract}
March 2006
Abstract: The aim of this paper is to examine the impact on bank stock prices of the Asian and Russian financial crises for a sample of European banks. This issue is of importance regarding financial fragility and contagion effects within the banking industry. We develop an event study methodology based on a large number of macroeconomic news and on public announcements of individual bank exposure during the sharpest episodes in 1997 and in 1998. Whereas bank stocks did not react promptly to the Asian crisis we show evidence of significant abnormal returns for a large number of banks to events of the Russian Crisis suggesting the presence of contagion effects.
\end{abstract}

JEL classification: G14, G21

Keywords: Asian and Russian crises; Banking; Event study; Contagion

\section{Introduction}

The two episodes of the Asian and Russian financial crises in the late 1990s led to a severe decline in stock prices on international capital markets. In Europe, bank stocks suffered from sharper fluctuations than average market indexes. In this context, the growing involvement of European banks in East Asian countries and in Russia during the late 1990s raises the issue of financial stability and contagion effects within the banking industry. This is important since the contagion hypothesis, if confirmed, has policy implications regarding the design of the safety net in response to financial crises.

•Corresponding authors. Tel.: +33-555-43-69-34 ; fax: +33-555-43-69-34 ; amine.tarazi@unilim.fr; laetitia.lepetit@unilim.fr ; celine.crouzille@unilim.fr. 
Beside Japanese banks, European banks expanded their activity in East Asian countries and they are extremely involved in Russia. For European banks, the share of loans in percentage of total international lending to Asian countries, increased from $51.9 \%$ in December 1994 to 58.1\% in June 1997 (BIS (1996), (1997)). In Russia, loans from European banks represented $88.9 \%$ of the total amount of international bank lending in December 1997 (BIS (1997), (1998(b))). A major concern was the extent to which European banks were actually exposed and suffered from the collapse in financial markets, debt defaults and exchange rate movements. European bank lending was led in Asia by German banks, followed by UK and French banks and in Russia by German banks, Swiss banks and to a lesser extent by French, Dutch, Austrian and Italian banks. At the end of 1996, the exposure of UK banks in Asia was mostly spread among three countries - South Korea, Thailand and Taiwan - and to a lesser extent Indonesia and Malaysia. Similarly to UK banks, French and German bank lending was also concentrated on South Korea and Thailand involving Indonesia as well (BIS (1997); 1998(b)). Before the crisis (end of 1996), German and UK banks reduced their exposures in South Korea and Thailand whereas French banks increased their loans in each of the five countries in which they were already involved. At the end of June 1997, German, French and UK banks had their strongest exposures in South Korea. For German and French banks, exposures were also notably high in Thailand.

The goal of this paper is to measure how news about macroeconomic difficulties and the deteriorating quality of bank portfolios due to country specific exposures affected the stock prices of European banks during these two episodes of financial crisis. We conduct an event study to analyse the pattern followed by individual bank stock returns for the largest possible sample of European banks. More specifically, our aim is to draw policy recommendations regarding the contagion hypothesis that is to assess whether non exposed banks need to be protected, along with exposed banks, under such circumstances.

The paper is laid out as follows. Section 2 discusses the link with the existing literature on the reaction of bank stock prices to financial crises. Section 3 describes the data and the choice of events enabling us to carry out an event study. Section 4 analyses the reaction of European bank stock prices to bank specific announcements and to general events of the Asian and Russian crises. Section 5 extends the empirical investigation to capture possible contagion effects and section 6 concludes. 


\section{Related literature}

The existing literature on the reaction of bank stock prices to financial crises is mainly dedicated to US banks. A large number of studies investigated the effect of announcements and news on stock returns by following an event-study methodology raising the issue of market efficiency and hence the speed and accuracy of the adjustment of stock prices to new public information. Event studies focusing on the presence of significant abnormal returns for US banks predominantly addressed the issue of the international debt crisis of the 80's or the Latin America currency crises of the 1990s (Cornell and Shapiro (1986), Mathur and Sundaram (1997), Kilic, Tufte and Hassan (1999), Bessler and Nohel (2000)). An important question raised in most papers is relative to the presence of contagion effects adversely affecting banks with low risk exposures as well as highly exposed banks. These contagion effects are of particular interest for banking institutions because of the central role played by banks and other financial intermediaries in systemic risk.

Amazingly, while banks have often been considered as being at the heart of the Asian and Russian financial crises, to our knowledge, only few exceptions focused on EU banks (Kho and Stulz (2000) and Rime (2003)). Examining the impact of the Asian crisis on bank stock indexes for both Western (US, France, Germany and the UK) and East Asian countries (Indonesia, Japan, Korea, Malaysia, Philippines and Thailand), Kho and Stulz (2000) report no significant abnormal returns for Western banks. Regarding the Russian financial crisis, Rime (2003) performed an event study for Swiss banks showing that stock returns were negatively affected by some of the most reported events with mixed evidence about contagion effects. Nevertheless, his results support the hypothesis that investors essentially discriminated among banks on the basis of broad categories (domesticallyoriented/internationally-oriented). In this paper, we focus on the reaction of European banks to both the Asian and the Russian financial crises by conducting an event study applied to individual bank stock data instead of bank stock indexes. We also take into account a large number of macroeconomic events but also bank specific events to capture possible contagion effects by estimating a multivariate model.

\section{Data set and description of the events}

Our sample consists of 109 European banks established in 11 countries (4 for Austria, 5 for Belgium, 23 for France, 8 for Germany, 30 for Italy, 5 for the Netherlands, 11 for 
Denmark, 3 for Ireland, 9 for Switzerland, 4 for Greece and 7 for the UK) all listed on official European stock markets. The financial institutions chosen to conduct our tests are commercial banks and mutual and cooperative banks. We excluded banks when their stocks were not continuously traded over our sample period. Daily stock indexes (European bank index, and domestic market indexes) and individual bank stock prices, for the 1996-1998 period, are taken from Datastream International and annual income statements and balance sheets for individual banks, from 1996 to 1998, come from Bankscope Fitch IBCA.

During the Asian and Russian crises, a large number of macroeconomic events affected the Asian and Russian financial markets. In this study we limited our choice to the most significant dates and periods reported in most studies (BIS (1998 (a)), BIS (1999), Kho and Stulz (2000) and King (2001)). We also considered announcements by European banks, which occurred within the crisis period, on their degree of exposure and the directly linked profit warnings. This information comes from Reuters' archives. In this sense we were able to gather both general macroeconomic announcements dates and individual bank specific announcement dates (see Table 1).

The macroeconomic announcements we consider for the Asian financial crisis include the two widely documented stages of the crisis ${ }^{1}$. The first stage began with the devaluation of the Thai bath on July 21997 (M_A3). This date corresponds to the beginning of the financial panic that spread to all East Asian "tigers" (Malaysia, Philippines and Singapore). The second stage began in late October 1997 when Taiwan devaluated its currency (M_A4) centered on Hong Kong and South Korea and spread to Indonesia and Taiwan. Financial turmoil occurred on October 22 in South Korea and Hong Kong (M_A5). On this same day Hong Kong raised official rates from 7 percent to 300 percent and Standard \& Poor's downgraded Korea's foreign debt causing a massive outflow of capital. On November 1, Indonesia closed 16 banks (M_A6) and on November 17 the Korean won sharply depreciated (M_A7). Two events are also selected before the beginning of the Asian crisis, reflecting the growing pressures on the Asian financial markets: on May 141997 speculative attacks occurred against the Thai bath (M_A1) and on June 25 1997, the Thai government withdrew its support to one of the major financial company (M_A2). Three individual bank specific announcements are also included in our event set (B_A1, B_A2 and B_A3). These events concern two British banks (HSBC and Standard Chartered) and one German bank (Dresdner Bank).

\footnotetext{
${ }^{1}$ King (2001) provides a detailed review of the Asian crisis.
} 
Table 1. Description of macro-economic and individual bank announcements

\begin{tabular}{|c|c|}
\hline $\begin{array}{l}\text { Event number and event } \\
\text { window }\end{array}$ & Description \\
\hline \multicolumn{2}{|r|}{ ASIAN CRISIS RELATED ANNOUNCEMENTS } \\
\hline \multicolumn{2}{|r|}{ Macroeconomic announcements } \\
\hline M_A1: 14/05/97 -15/05/97 & Speculative attacks against the Thai bath \\
\hline M_A2: 25/06/97 -26/06/97 & Thai government withdrew its support to one of the major financial company \\
\hline M_A3: 02/07/97 -03/07/97 & Floating of the Thai bath \\
\hline M_A4: $17 / 10 / 97-20 / 10 / 97$ & Taiwan devaluated its currency \\
\hline M_A5: $22 / 10 / 97-23 / 10 / 97$ & Financial turmoil in Hong Kong and South Korea \\
\hline M_A6: 31/10/97-03/11/97 & Closure of 16 Indonesian banks \\
\hline M_A7: 17/11/97-18/11/97 & Depreciation of the Korean won \\
\hline \multicolumn{2}{|r|}{ Individual bank announcements } \\
\hline B_A1:21/07/97-22/07/97 & Rumours over Standard Chartered looses related to its activity in Asia \\
\hline B_A2: 20/08/97-21/08/97 & Goldman and Sachs downgraded HSBC and Standard Chartered Bank \\
\hline B_A3:28/11/97-01/12/97 & $\begin{array}{l}\text { Dresdner Bank announced an increase of its provisions to cover credit } \\
\qquad \text { exposure in Asia }\end{array}$ \\
\hline \multicolumn{2}{|r|}{ RUSSIAN CRISIS RELATED ANNOUNCEMENTS } \\
\hline \multicolumn{2}{|r|}{ Macroeconomic announcements } \\
\hline M_R1:17/08/98-18/08/98 & $\begin{array}{l}\text { Modification of the exchange rate regime in Russia, and suspension of interest } \\
\text { payments on public debt }\end{array}$ \\
\hline M_R2: 26/08/98-27/08/98 & Floating of the rouble \\
\hline M_R3: 01/09/98-02/09/98 & Authority stop supporting the rouble \\
\hline \multicolumn{2}{|r|}{ Individual bank announcements } \\
\hline B_R1:28/07/98-29/07/98 & Dresdner Bank announced the level of its exposure in Russia \\
\hline B_R2: 25/08/98 & UBS announced the level of its exposure in Russia \\
\hline B_R3: 28/08/98-29/08/98 & Deutsche Bank announced the level of its exposure in Russia \\
\hline B_R4: 03/09/98-07/09/98 & Credit Suisse announced the level of its exposure in Russia \\
\hline B_R5: 08/09/98 & ABN Amro announced the level of its exposure in Russia \\
\hline B_R6: 09/09/98-10/09/98 & $\begin{array}{l}\text { Société Générale and BNP Paribas announced the level of their exposure in } \\
\text { Russia }\end{array}$ \\
\hline B_R7: 30/09/98-02/10/98 & Dresdner Bank announced a decrease in profit related to its exposure in Russia \\
\hline B_R8: 05/10/98-06/10/98 & Deutsche Bank announced a decrease in profit compared to the expected one \\
\hline B_R9: 09/10/98-10/10/98 & ING announced an estimated cut in the profit of $15 \%$ to $35 \%$ \\
\hline
\end{tabular}

In the case of the Russian crisis, speculative attacks against the Rouble began during the first semester of 1998. The deepening of the financial difficulties led the authorities to widen the band of fluctuation of the exchange rate and to suspend interest payments on public debt on August 17 (M_R1). On August 26, Russian authorities officially let the rouble floating (M_R2). The government stopped supporting the rouble on September 1 (M_R3). 
Nine individual bank specific announcements (B_R1, B_R2, B_R3, B_R4, B_R5, B_R6, B_R7, B_R8 and B_R9), involving two German banks (Dresdner Bank and Deutsche Bank), two French banks (Société Générale and BNP-Paribas), two Swiss banks (UBS and Credit Suisse) and two Dutch banks (ING and ABN Amro), are also considered. Table 1 summarizes our set of macro-economic and individual bank announcements.

\section{Reaction of banks' stock prices to macro and individual bank announcements}

\subsection{Event study methodology}

We use an event-study methodology based on the market model to test for the presence of abnormal returns during the Asian and Russian crises. To deal with clustering effects and industry induced correlation of returns, we estimate a multivariate regression model based on Zellner's (1962) seemingly unrelated regressions (SUR) methodology. Number of studies employed this procedure to analyze the reaction of US bank stocks to either international debt crises or currency crises (Cornett and Tehranian (1990), Madura et al. (1992), Unal et al. (1993), Mathur and Sundaram (1997) and Lau and McInish (2003)). In our study, two types of estimations are conducted: estimations based on industry level data and estimations based on individual bank data. The multivariate estimated model is the following:

$$
\left\{\begin{array}{l}
\mathrm{R}_{1, \mathrm{t}}=\alpha_{1}+\beta_{1} \mathrm{R}_{\mathrm{M}, \mathrm{t}}+\gamma_{1} \mathrm{R}_{\text {EUBANK }, \mathrm{t}}+\sum_{\mathrm{j}=1}^{22} \delta_{1, \mathrm{j}} \mathrm{D}_{\mathrm{j}, \mathrm{t}}+\varepsilon_{1, t} \\
\mathrm{R}_{2, \mathrm{t}}=\alpha_{2}+\beta_{2} \mathrm{R}_{\mathrm{M}, \mathrm{t}}+\gamma_{2} \mathrm{R}_{\text {EUBANK }, \mathrm{t}}+\sum_{\mathrm{j}=1}^{22} \delta_{2, \mathrm{j}} \mathrm{D}_{\mathrm{j}, \mathrm{t}}+\varepsilon_{2, t} \\
\cdot \\
\mathrm{R}_{\mathrm{i}, \mathrm{t}}=\alpha_{\mathrm{i}}+\beta_{\mathrm{i}} \mathrm{R}_{\mathrm{M}, \mathrm{t}}+\gamma_{\mathrm{i}} \mathrm{R}_{\text {EUBANK }, \mathrm{t}}+\sum_{\mathrm{j}=1}^{22} \delta_{\mathrm{i}, \mathrm{j}} \mathrm{D}_{\mathrm{j}, \mathrm{t}}+\varepsilon_{i, t}
\end{array}\right.
$$

where $\mathrm{R}_{\mathrm{i}, \mathrm{t}}$ is either the rate of return on the stock of bank $i$ on day $t$ (for estimations based on individual data) or the rate of return on the bank stock index of country $i$ on day $t$ (for estimations based on industry data); $\mathrm{R}_{\mathrm{M}, \mathrm{t}}$ is the return of the national market index; $\mathrm{R}_{\text {EUBANK,t }}$ is the return of the European bank stock index provided by Datastream International. 
For each of the 22 events, indexed $j$ and presented in Table 1, we define a dummy variable $D_{j, t}$ taking the value of 1 the event day and the day after ${ }^{2}$ and 0 elsewhere. The coefficient $\delta_{\mathrm{i}, \mathrm{j}}$ of the dummy variable $\mathrm{D}_{\mathrm{j}, \mathrm{t}}$ captures the effect of event $j$ for bank $i$ or for the banking index of country $i$. Abnormal returns are captured by the statistical significance of the related coefficients. A negative and significant sign is expected when the market anticipates a negative impact of the considered event for bank $i$. Therefore, we only focus on negative reactions. Because we simultaneously include the dummies related to the Asian and Russian events, the system of equations (1) is estimated from January 11996 to December $311998^{3}$.

\subsection{Industry level and individual bank results}

Before considering our sample of individual banks, we first conduct our event study at the industry level. Regarding the Asian crisis, only 4 domestic banking systems (Austrian, Greek, Dutch and Swiss) experience a negative significant reaction and only for 1 out of the 10 considered events ${ }^{4}$. These findings are not consistent with the hypothesis that the market should experience the strongest reaction for the most involved banking systems in Asian countries (i.e. British, French and German). It seems that the market was caught out by the Asian crisis and that the sharp decrease in the market as a whole (all industries and sectors) might have mitigated bank specific effects. However, regarding the Russian crisis the market reaction was stronger which is in line with the relatively stronger involvement of European banks in Russia. Indeed, our results show that the market significantly reacts for a greater number of banking indexes for events related to the Russian crisis. Except for the Irish system, the coefficients of the dummy variables are significant and negative at least for one of the selected 12 events. The French banking system, one of the most involved in Russia, experiences the highest number of significant reactions ( 4 out of 12 events). Conversely, for the German banking system, which on the whole presented the highest level of exposure to Russia, market prices exhibit significant abnormal returns only for 1 event.

Tables 2, 3 and 4 sum up the estimation results for the 109 European banks of our sample. We first study, for each crisis and for each type of event (macroeconomic announcements and individual bank announcements) the negative reaction of the market to

\footnotetext{
${ }^{2}$ For two of the considered events (B_R2 and B_R5) the event windows overlap with another event window. To avoid confusion we restricted event windows to event days.

${ }^{3}$ We also conducted separate estimations for each crisis (from January 011996 to December 311997 for the Asian crisis and from January 011997 to December 311998 for the Russian Crisis). The results remained unchanged.

${ }^{4}$ The results of industry level estimations are not presented in the paper but are available from the authors upon request.
} 
the different events. The results obtained at the individual bank level support those obtained above on the basis of bank indexes revealing a stronger reaction for the Russian crisis. For the Asian crisis only 21 significant market reactions are obtained against 124 for the Russian crisis (Tables 2 and 3). Out of the 21 significant reactions obtained for the Asian crisis (respectively 124 for the Russian crisis), 15 (respectively 30 for the Russian crisis) are related to macroeconomic announcements and 6 (respectively 94 for the Russian crisis) are related to individual bank announcements. The higher number of significant negative reactions for the Russian crisis is in line with the heavier exposure of European banks in Russia outlined previously ${ }^{5}$.

Table 4 shows for each crisis and each type of event, the number of banks for which a negative and significant market reaction is obtained for at least one event. For the Asian crisis, the 21 significant reactions we obtain in our estimations are relative to 21 different banks whereas the 124 significant reactions regarding the Russian crises are distributed among 70 banks. Also, in the case of the Russian crisis, several significant reactions can be witnessed for the same bank. Furthermore, out of the 21 banks for which a negative market reaction is observed during the Asian crisis, 14 also present abnormal returns during the Russian crisis.

\footnotetext{
${ }^{5}$ In this study we solely focus on negative reactions. Therefore, in Tables 2,3 and 4 we only present the percentage of banks with a negative market reaction. However, other results, which are not presented here but are available on request, show that the percentage of significant and positive market reactions for all the events is $4.22 \%$ (46 reactions) for the Asian crisis and 5.88\% (77 reactions) for the Russian crisis.
} 
Table 2. Market reaction to Asian crisis related events for individual banks (number of negative and significant abnormal reactions for each event)

\begin{tabular}{|c|c|c|c|c|c|c|c|c|c|c|c|c|}
\hline \multicolumn{7}{|c|}{ Macroeconomic announcements } & \multirow{2}{*}{$\begin{array}{l}\text { Number of reactions to } \\
\text { macroeconomic } \\
\text { announcements }\end{array}$} & \multicolumn{3}{|c|}{$\begin{array}{l}\text { Individual bank } \\
\text { announcements }\end{array}$} & \multirow{2}{*}{$\begin{array}{l}\text { Number of reactions } \\
\text { to individual bank } \\
\text { announcements }\end{array}$} & \multirow[t]{2}{*}{$\begin{array}{c}\text { Total number } \\
\text { of reactions }\end{array}$} \\
\hline M_A1 & M_A2 & M_A3 & M_A4 & M_A5 & M_A6 & M_A7 & & B_A1 & B_A2 & B_A3 & & \\
\hline $\begin{array}{c}2 \\
(1.83 \%) \\
\end{array}$ & $\begin{array}{c}4 \\
(3.36 \%) \\
\end{array}$ & $\begin{array}{c}4 \\
(3.36 \%) \\
\end{array}$ & 0 & $\begin{array}{c}3 \\
(2.75 \%) \\
\end{array}$ & $\begin{array}{c}1 \\
(0.92 \%)\end{array}$ & $\begin{array}{c}1 \\
(0.92 \%)\end{array}$ & $\begin{array}{c}15 \\
(1.96 \%) \\
\end{array}$ & $\begin{array}{c}2 \\
(1.83 \%) \\
\end{array}$ & $\begin{array}{c}2 \\
(1.83 \%) \\
\end{array}$ & $\begin{array}{c}2 \\
(1.83 \%) \\
\end{array}$ & $\begin{array}{c}6 \\
(1.83 \%) \\
\end{array}$ & $\begin{array}{c}21 \\
(1.93 \%) \\
\end{array}$ \\
\hline
\end{tabular}

(): number of negative market reactions in \% of the total number of banks of our sample.

(): average number of significant negative market reactions per event in \% of the total number of banks of our sample.

Table 3. Market reaction to Russian crisis related events for individual banks (number of negative and significant abnormal reactions for each event)

\begin{tabular}{|c|c|c|c|c|c|c|c|c|c|c|c|c|c|c|}
\hline \multicolumn{3}{|c|}{$\begin{array}{l}\text { Macroeconomic } \\
\text { announcements }\end{array}$} & \multirow{2}{*}{$\begin{array}{l}\text { Number of } \\
\text { reactions to } \\
\text { macroeconomic } \\
\text { announcements }\end{array}$} & \multicolumn{9}{|c|}{ Individual bank announcements } & \multirow{2}{*}{$\begin{array}{c}\text { Number of } \\
\text { reactions to } \\
\text { individual } \\
\text { bank } \\
\text { announcements }\end{array}$} & \multirow{2}{*}{$\begin{array}{c}\text { Total } \\
\text { number } \\
\text { of } \\
\text { reactions }\end{array}$} \\
\hline M_R1 & M_R2 & M_R3 & & B_R1 & B_R2 & B_R3 & B_R4 & B_R5 & B_R6 & B_R7 & B_R8 & B_R9 & & \\
\hline
\end{tabular}

\begin{tabular}{|c|c|c|c|c|c|c|c|c|c|c|c|c|c|c|}
\hline $\begin{array}{c}3 \\
(2.75 \%)\end{array}$ & $\begin{array}{c}14 \\
(12.84 \%)\end{array}$ & $\begin{array}{c}13 \\
(11.92 \%)\end{array}$ & $\begin{array}{c}30 \\
(9.17 \%)\end{array}$ & $\begin{array}{c}3 \\
(2.75 \%)\end{array}$ & $\begin{array}{c}5 \\
(4.59 \%)\end{array}$ & $\begin{array}{c}8 \\
(7.33 \%) \\
\end{array}$ & $\begin{array}{c}21 \\
(19.27 \%)\end{array}$ & $\begin{array}{c}7 \\
(6.42 \%)\end{array}$ & $\begin{array}{c}11 \\
(10.09 \%)\end{array}$ & $\begin{array}{c}20 \\
(18.35 \%)\end{array}$ & $\begin{array}{c}10 \\
(9.17 \%)\end{array}$ & $\begin{array}{c}9 \\
(8.26 \%)\end{array}$ & $\begin{array}{c}94 \\
(9.58 \%)\end{array}$ & $\begin{array}{c}124 \\
(9.48 \%)\end{array}$ \\
\hline
\end{tabular}

(): number of negative market reactions in \% of the total number of banks of our sample.

(): average number of significant negative market reactions per event in \% of the total number of banks of our sample.

Table 4. Number of banks for which at least one negative and significant reaction is obtained for each crisis and each type of event

\begin{tabular}{lccc} 
& Macroeconomic announcements & Individual bank announcements & All events taken together \\
\hline \hline Asian Crisis & 15 & 6 & 21 \\
Russian Crisis & 32 & 60 & 70 \\
\hline \hline
\end{tabular}




\section{Market reaction and bank exposure announcements}

In order to determine which factors can explain the probability for a bank to be affected by a negative market reaction during the two crises, and also to test for the presence of contagion effects, we first provide descriptive statistics on the relationship between market reactions and bank exposure announcements. We then further analyse this relationship with logit estimations ${ }^{6}$.

Two types of binary variables are computed related to market reactions and bank exposure announcements.

Firstly, building on the results obtained in the previous section, we computed for the Russian crisis event binary variables, which take for bank $i$ the value of 1 when a significant market reaction (at the 5\% level) is obtained in our estimations and 0 otherwise. We deliberately ignored all the events for which we obtain too few observations which take the value of 1 , that is all the events related to the Asian crisis. We also defined a binary variable named RUSSIATOT $\mathrm{i}_{\mathrm{i}}$, which takes for bank $i$ the value of 1 when a significant reaction of the market is obtained at least one time out of the different events $j$ (at the $5 \%$ level) and 0

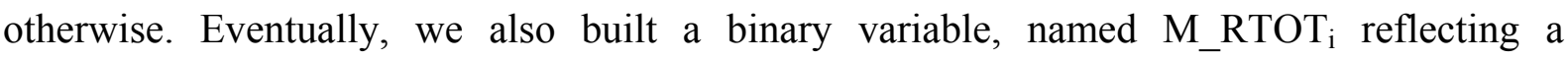
significant reaction of the market for bank $i$ at least one time out of the three macroeconomic announcements events of the Russian crisis and 0 otherwise.

Secondly, since bank country exposures are not reported in Bankscope, we used information provided by Reuters' archives and annual bank reports to define two sets of binary variables: (i) a variable D_expo, which takes the value of 1 when a bank publicly announced its degree of exposure during the crisis period and 0 otherwise; (ii) for each event $j$, a variable, D_expobeforej, which takes the value of 1 when a bank publicly revealed its degree of exposure before event $j$ and 0 otherwise.

In our sample, out of the 12 banks which publicly revealed their exposure in Russia ${ }^{7}$, 10 exhibited a significant reaction (2 French banks, 2 German banks, 2 Dutch banks, 1 Swiss

\footnotetext{
${ }^{6}$ We also analysed the relationship between significant stock price reactions and bank characteristics by regressing stock price reactions on a set of variables (bank size, structure of bank balance sheets and income statements and capital adequacy). Our results suggest that market operators did not discriminate among banks on the basis of their general profiles.

${ }^{7}$ These twelve banks are: Commerzbank (Germany), UBS (Switzerland), Deutsche Bank (Germany), ABN Amro (Netherlands), Bayerische Hypo-und Vereinsbank (Austria), Dresdner Bank (Germany), Bank Austria (Austria), Crédit Suisse (Switzerland), Barclays Bank (UK), BNP (France), Société Générale (France) and ING Bank (Netherlands).
} 
bank, 1 British bank and 2 Austrian banks). Among these 12 banks, the market significantly reacted, at least once, for 9 banks which had announced their degree of exposure before the event date. Conversely, the market also significantly reacted at least once during the Russian crisis for 60 banks which had not announced their exposures suggesting the presence of contagion effects. We also examine for each bank the distribution of significant market reactions and its relationship with individual bank exposure. Since, in our sample, the maximum number of abnormal returns for each bank is limited to 4 , we define 4 reaction classes all regarding the Russian crisis: (i) no reaction: banks which never exhibit abnormal returns during the Russian crisis; (ii) low reaction: only 1 significant reaction; (iii) intermediate reaction: 2 significant reactions; (iv) high reaction: at least 3 significant reactions. As shown in Table 5, out of the 109 banks of our sample, 39 never exhibit significant abnormal returns whereas the market frequently reacted for 12 banks of which only 3 had announced their exposures.

The event binary variables were then regressed (logit estimation) on each exposure proxy. We follow here the methodology proposed by Cornel and Shapiro (1986) and Unal et al. (1993) to test the contagion hypothesis. Whereas these authors examine contagion by regressing (OLS estimations) abnormal returns on actual loan exposure, we here use the binary variables D_expo and D_expobejorej in a Logit setting because information on actual individual exposure is not available for a large number of banks in our sample. The results, presented in Table 6, show that the coefficient of D_expo is never significant. This absence of positive and significant coefficient of the independant variables is consistent with the contagion effect hypothesis. Higher exposure which is publicly announced does not significantly contribute to explain negative abnormal returns and banks with a low exposure suffered from significant falls in stock prices as well as highly exposed banks.

However, the variable D_expobeforej is significant at the $1 \%$ level for 5 events out of 8. For 4 of these events the coefficients are negative and highly significant. Consequently, exposure announcements before an event tend to reduce the probability for bank stocks to exhibit abnormal returns suggesting that the market had already integrated the news, good or bad, before the event date (a finding which supports the semi-strong efficiency hypothesis). Therefore, when banks reveal their exposures before a given event actually occurs or before a crisis is publicly announced, market participants might well be lenient with these banks but "punish" the other banks. Contagion effects might in this case be limited to the subset of non announcing banks. 
Table 5. Distribution of significant market reactions

\begin{tabular}{|c|c|c|c|c|c|}
\hline Number of banks & No reaction & Low reaction & Intermediate reaction & High reaction & Total \\
\hline \multicolumn{6}{|c|}{ Out of the total number of banks } \\
\hline & $\begin{array}{c}39 \\
(35.78 \%)\end{array}$ & $\begin{array}{c}31 \\
(28.44 \%)\end{array}$ & $\begin{array}{c}27 \\
(24.77 \%)\end{array}$ & $\begin{array}{c}12 \\
(11.01 \%)\end{array}$ & 109 \\
\hline \multicolumn{6}{|c|}{ Out of the total number of announcing banks } \\
\hline & $\begin{array}{c}2 \\
(16.67 \%)\end{array}$ & $\begin{array}{c}2 \\
(16.67 \%)\end{array}$ & $\begin{array}{c}5 \\
(41.66 \%)\end{array}$ & $\begin{array}{c}3 \\
(25 \%)\end{array}$ & 12 \\
\hline
\end{tabular}

Table 6. Market reaction and bank exposure announcement

\begin{tabular}{|c|c|c|c|c|c|c|c|c|c|c|}
\hline & \multicolumn{10}{|c|}{ Dependent variable } \\
\hline & B_R3 & M_R3 & B_R4 & B_R5 & B_R6 & B_R7 & B_R8 & B_R9 & M_RTOT & RUSSIATOT \\
\hline \multirow[t]{2}{*}{ D_expobeforej } & $-31.018 * * *$ & $-31.428 * * *$ & $1.78 * * *$ & $-30.09 * * *$ & $2.17 * * *$ & $1.23 *$ & -0.34 & $1.53^{*}$ & & \\
\hline & $(-56.92)$ & $(-72.50)$ & $(2.45)$ & $(-60.61)$ & $(2.87)$ & $(1.78)$ & $(-0.32)$ & $(1.65)$ & - & - \\
\hline D_expo & - & - & - & - & - & - & - & - & $\begin{array}{c}-0.186 \\
(-0.165)\end{array}$ & $\begin{array}{c}1.126 \\
(1.403)\end{array}$ \\
\hline Dependent variable $=1$ & 96 & 90 & 95 & 102 & 99 & 91 & 97 & 103 & 77 & 39 \\
\hline Dependent variable $=0$ & 13 & 19 & 14 & 7 & 10 & 18 & 12 & 6 & 32 & 70 \\
\hline
\end{tabular}




\section{Conclusion}

The objective of this paper was to examine the reaction of European bank stock prices to events of the Asian and Russian financial crises. Based on a sample of 109 listed banks and a set of macroeconomic announcements and individual bank public announcements, our study first shows that whereas bank stock prices did not react to the Asian crisis, they exhibited significant abnormal returns in response to several events of the Russian Crisis. Using bank public announcements to proxy country exposures of loan portfolios, we find a strong link between bank stock reaction and bank individual news. However, bank stocks are also sensitive to news specific to other banks suggesting evidence of possible contagion effects.

\section{References}

Bessler W. and T. Nohel (2000): "Asymmetric information, dividend reductions and contagion effects in bank stock returns", Journal of Banking and Finance, 24, pp 1831-1848. BIS (1996): Bank for International Settlement, consolidated international banking statistics. BIS (1997): Bank for International Settlement, consolidated international banking statistics. BIS (1998 (a)): Bank for International Settlement, Annual Report, June.

BIS (1998 (b)): Bank for International Settlement, consolidated international banking statistics.

BIS (1999): Bank for International Settlement, Annual Report.

Cornell B. and A. Shapiro (1986): "The reaction of bank stock prices to the international debt crisis", Journal of Banking and Finance, 10, pp 55-73.

Cornett M. and H. Tehranian (1989): "Stock market reactions to the Depository Institutions Deregulation and Monetary Control Act of 1980", Journal of Banking and Finance, 13, pp $81-100$.

Kho B.C. and R. Stulz (2000): "Banks, the IMF, and the Asian crisis", Pacific-Basin Finance Journal, 8, pp 177-216.

Kilic O.D. Tufte and M. Hassan (1999): “The 1994-1995 Mexican currency crisis and US bank stock return”, Journal of Financial Services Research, 16(1), pp 47-60.

King M.R. (2001): "Who triggered the Asian financial crisis", Review of International Political Economy, 8:3, Autumn, pp 438-446. 
Lau S. and T. McInish (2003): "IMF bailouts, contagion effects and bank security returns", International Review of Financial Analysis, 12, pp 3-23.

Madura J., Tucker A. and E. Zarruck (1992): "Reaction of bank share prices to the thirdworld debt reduction plan", Journal of Banking and Finance, 16, pp 853-868.

Mathur I. and S. Sundaram (1997): "Reaction of bank stock prices to the multiple events of the Brazilian debt crisis", Applied Financial Economics, 7, pp 703-710.

Rime B. (2003): “The Reaction of Swiss Banks' Stock Prices to the Russian Crisis”, Schweiz Zeitschrift für Volkswirtschaft und Statistik, 139.

Unal H., Demirguc-Kunt A. and K. Leung (1993): “The Brady Plan, 1989 Mexican debt reduction agreement and bank stock returns in United States and Japan”, Journal of Money, Credit and Banking, 25, pp 410-429.

Zellner A. (1962): “An efficient method for estimating seemingly unrelated regressions and tests for aggregations bias", Journal of the American Statistical Association, 57, pp 348-368. 